\title{
Pulmonary Functions between Active and Passive Smoking in 18-22 Years Old Male Physical Education Students - A Descriptive Study
}

\author{
Hayati $^{1, \mathrm{a}}$, Billy Emir Rizkanto ${ }^{2}$, Santika Rentika Hadi $^{3}$, Achmad Nuryadi $^{4}$, \\ Ridha Amalia ${ }^{5}$
}

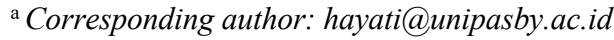

${ }^{1}$ Doctoral of Sport Science, Medical Doctor of Clinical Exercise Physiologist, Faculty of Pedagogy and Psychology, Universitas PGRI Adi Buana, Surabaya, Indonesia

${ }^{2}$ Master of Sport Education, Faculty of Pedagogy and Psychology, Universitas PGRI Adi Buana, Surabaya, Indonesia

${ }^{3}$ Doctoral of Sport Science, Faculty of Pedagogy and Psychology, Universitas PGRI Adi Buana, Surabaya, Indonesia

${ }^{4}$ Master of Sport Education, Faculty of Pedagogy and Psychology, Universitas PGRI Adi Buana, Surabaya, Indonesia

${ }^{5}$ Medical Doctor, Surabaya, Indonesia

\begin{abstract}
To assess and describe the vital capacity (VC), forced vital capacity (FVC), forced expiratory volume in one second (FEV1), and the ratio of FEV1/FVC measurements in smoking male physical education students, ranged between $18-22$ years. Also compare the FEV1 and ratio of FEV1/FVC between active and passive smoker. A cross-sectional study was applied on male physical education students $(\mathrm{n}=30)$ who undergo training for 2 months and between the age range of 18-22 years old. The lung VC, FVC, FEV1, and ratio of FEV1/FVC were measured and compared between active and passive smokers. Thirty male physical education students participated in this study with the average age of 19,53 $\pm 0,86$ years old. All participants underwent training for 2 months in Surabaya. The average BMI was 23,16 $\pm 4,624$. The active to passive smoker ratio was 7:3, with 21 active smokers and 7 passive smokers. The results of all pulmonary function tests in passive smokers were better than in active smokers. The average of $\mathrm{VC}$ in passive smokers was $3,45 \pm 0,498$, slightly higher than $\mathrm{VC}$ in active smokers which was $3,35 \pm 1,032$. The FVC average in passive smoker was $3,56 \pm 0,489$, also higher than active smoker with $3,43 \pm 0,671$. The higher FEV1 mean was in passive smoker with $1,84 \pm 0,856$, compared to active smoker with 1,53 $\pm 0,595$. Similar results also could be seen in FEV1/FVC ratio. The FEV1/FVC ratio average in passive smokers was 2,39 $\pm 5,094$, higher than those in active smokers with $0,60 \pm 0,205$. In this study, the total participants with normal results were higher in passive smoker which was $3(33,333 \%)$ participants, and only $1(4,761 \%)$ in active smoker. For moderate COPD, active smoker was higher with $3(14,286 \%)$ participants, while passive smoker with moderate COPD was $2(22,222 \%)$ participants. The amount of severe COPD was high in active smokers with $13(61,905 \%)$ participants, and only $1(11,111 \%)$ in passive smokers. Meanwhile the active smoker with very severe COPD was $4(19,047 \%)$ participants, and in the passive smoker was $3(33,333 \%)$ very severe COPD. Active and passive smokers have an equally greater risk of lung tissue damage. Most of the free radical (OH-) in cigarette will arrive at the alveolus that can damage the lungs while smoking cigarettes in active smoker or inhale cigarette smoke in passive smoker.
\end{abstract}

Keywords: VC, FVC, FEVI, FEVI/FVC, pulmonary function test, physical education students, smoker, active smoker, passive smoker 


\section{Introduction}

The number of smokers in Indonesia is very high even among the highest groups in the world. Based on the latest data from the Global Youth Tobacco Survey (GYTS) in 2019 that $40.6 \%$ of students aged 13-15 years, 2 out of 3 boys, and 1 in 5 girls have used tobacco products: 19.2\% (WHO, 2020)

There are two kinds of smokers, which are active and passive smokers. An active smoker is someone who intentionally sucks a roll or roll of tobacco wrapped usually with paper, leaves, and corn skin. They also inhale the cigarette smoke they exhale from their mouths. Meanwhile the definition of passive smoker is a person or group of people who inhale other people's cigarette smoke. (bantenprov.go.id,2017)

Smoking is dangerous because every year according to WHO in Indonesia 225,700 people die from smoking and other tobacco-related diseases. Smoking can cause various diseases such as lung cancer, cardiovascular disease, risk of the occurrence of neoplasm larynx, oesophagus (WHO, 2020).

The lungs are the main organs of respiration that have the function of obtaining oxygen and removing carbon dioxide. Lung function can be measured by lung function tests including Vital Capacity (VC), Forced Vital Capacity (FVC) and Forced Expiratory Volume in 1 second (VEF1). Many factors that can decrease lung function include Chronic Obstructive Pulmonary Disease (COPD) which is often caused by smoking. Lungs affected by exposure to cigarette smoke every day will experience changes in function, two of which are decreased KVPand VEP1. Changes in pulmonary function cause a state of restriction and obstruction, it causes COPD that causes losses in the long term (Lontoh, 2019).

Cigarettes are a combination of chemicals with three types of most dangerous chemicals such as tar, nicotine and carbon monoxide gas (Kusuma, 2020). Cigarettes produce imperfect combustion and will secrete 4000 chemicals deposited in the body when smoked. According to the World Health Organization (WHO), smoking cigarette will cause various diseases in active and passive smokers. Smoking can cause various diseases such as lung cancer, cardiovascular disease, risk of the occurrence of neoplasm larynx, esophagus (WHO, 2020).

The dangers of smoking can be demonstrated by the number of deaths from cigarettes or tobaccorelated diseases around 225,700 people in Indonesia (WHO, 2020). Without control efforts, during the 21st century at least one billion people in the world will die in vain, 10 times more than the death from smoking in the 20th century. The current 5.4 million people who die because of smoking will rise to 80 million annually by 2030 and 80 percent will occur in developing countries. The death rate from tobacco is much higher than deaths from HIV/AIDS, tuberculosis and malaria. Various diseases can arise in active and passive smokers in almost any part of the human body (Rachmat, 2016).

Aerobic exercise has a positive impact on smokers otherwise also has a negative impact. Exercise can improve metabolic, cardiovascular and respiratory conditions that can improve fitness, but smokers who already have changes in organ physiology, especially in the cardiovascular system, actually show a negative impact. Exercise can increase the antioxidants needed to overcome free radicals in smokers so that there can be an increase in the immune system.

Quitting smoking is the best solution, but the difficulty of stopping smoking requires us to look for alternative preventive efforts that can reduce the adverse effects of smoking, one of which is by exercising such as aerobic exercise that have been shown to improve lung function, which can be detected using pulmonary function tests.

There are many parameters in pulmonary function tests, such as Vital Capacity (VC), Forced Vital Capacity (FVC), Forced Expiratory Volume, etc. Vital Pulmonary Capacity (VC) is the maximum amount of inspiring and expiratory air after regular inspiration and expiration. Forced Vital Capacity (FVC) is the volume of gas that can be released as strongly and as quickly as possible after maximum inspiration. Measurements are carried out with maximum forced expiratory effort where the patient is asked with the strongest and immediately release vital capacity. Forced Expiratory Volume is the volume of gas released during a specified time interval, measured at the time of carrying out forced vital capacity/FVC measurements. Intervals can be $0.5,1,2$, or 3 
seconds so that FEV0.5 is obtained; FEV1.0; FEV 2.0 and FEV 3.0. Forced expiratory volume (FEV1) is the amount of air that can be released as much as possible in the first 1 second at maximum expiration time after maximum inspiration (Bakhtiar and Tantri, 2019).

\section{Materials and Methods}

A cross-sectional study was applied on 30 male physical education students in Surabaya, East Java, Indonesia. The examination was performed in December 2021, $15^{\text {th }}$ at 8.00-12.00 a.m. As the preparation of the participants before research are explained below:

a. Aerobic exercise is a 1200 meter running exercise with a frequency of 3x/week for 6 weeks preceded by warming up, stretching and ending cooling down.

b. The sample fills out the inform concern as evidence that the person concerned is willing to engage in research.

The athletes were males who underwent training for 2 months and between the age range of 18-22 years old. The participants are divided into active and passive smokers. All participants who were currently smoking, or having a history of smoking were classified into active smokers. Those who only inhaled the smoke from their environment were the passive smokers.

\section{Anthropometric parameters}

The body weight of participants was measured on a scale with $0.1 \mathrm{~kg}$ readability. The participants didn't use any footwear, and wore light clothes. The height of participants was measured using a stadiometer with $0.1 \mathrm{~cm}$ readability. Same as before, the participants were also barefoot and wearing thin clothes. The body mass index is defined as the ratio of the mass of body in kilograms, divided by body height in meters squared. The underweight was below 18.5 , normal between range of $18-5$ to 24.9 , overweight was 25.0-29.9, and obese was above 30.0 .

\section{Spirometry}

For the tool preparation, first we provided mouth pieces as many as the number of research samples. Then we connected the Autospiro with power sources and ensured that the Autospiro could run well. The machine series was AS-507 Spirometry by Minato. The examination was conducted under temperature 26.0 C, humidity level $60 \%$. Participants performed the test in standing position, wore a nose clip properly, and held the spirometry in their right hand.

The lung VC, FVC, FEV1, and ratio of FEV1/FVC were measured in both active and passive smokers' categories and described. For the $\mathrm{VC}$ measurement, the athletes were asked to do maximum inspiration and expiration. For the FVC, we measured the volume of gas that could be released as strongly and as quickly as possible after the athletes did maximum inspiration. FEV1 was measured by telling the athlete to release maximum expiration in the first 1 second after maximum inspiration. The results of FEV1 were divided by $\mathrm{FVC}$, to count the FEV1/FVC ratio. This ratio is used to classify the athletes into 2 categories, those who have Chronic Obstructive Pulmonary Disease, and those with normal results.

\section{Statistical Analysis}

The statistic in this study was performed using IBM SPSS program version 21, a statistical software. The demographic data, the measurement results and spirometry results were analysed descriptively.

\section{Results and Discussion}

Thirty students participated in this study. The male to female ratio was 30:0 and average age was 19,53 $\pm 0,86$ years old. All participants underwent training for 2 months in Surabaya. The average BMI was 23,16 \pm 4,624. The active to passive smoker ratio was 7:3, with 21 active smokers and 7 passive smokers. The demographic and anthropometric data are shown in Table 1. 
Table 1. The Demographic and Anthropometric Data.

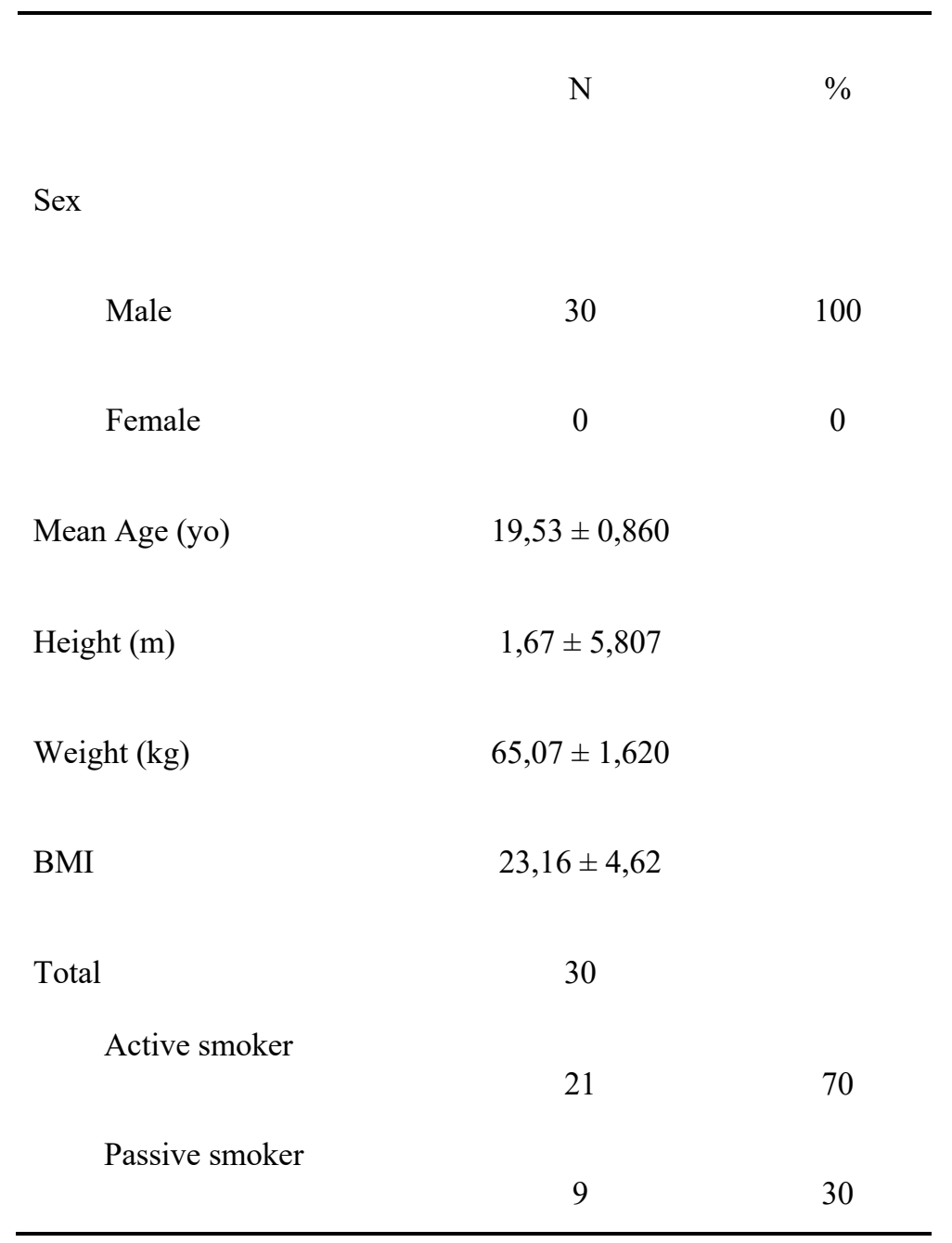

The VC, FVC, FEV1, and FEV1/FVC ratio in active smoker athletes were measured simultaneously with the passive smokers. In table 2 and figure 1 below, the results of all pulmonary function tests in passive smokers were better than in active smokers. The average of VC in passive smokers was $3,45 \pm 0,498$, slightly higher than VC in active smokers which was 3,35 $\pm 1,032$. The FVC average in passive smoker was 3,56 \pm 0,489 , also higher than active smoker with $3,43 \pm 0,671$. The higher FEV1 mean was in passive smoker with $1,84 \pm 0,856$, compared to active smoker with $1,53 \pm 0,595$. Similar results also could be seen in FEV1/FVC ratio. The FEV1/FVC ratio average in passive smokers was 2,39 $\pm 5,094$, higher than those in active smokers with $0,60 \pm 0,205$. (Table 2) (Figure 1). 
Table 2. The Comparison of Pulmonary Function Test in Active and Passive Smoker Athletes.

\begin{tabular}{lcc}
\hline & Active Smoker & Passive Smoker \\
\hline $\mathrm{n}$ & 21 & 9 \\
$\mathrm{VC}$ & $3,35 \pm 1,032$ & $3,45 \pm 0,498$ \\
& & \\
FVC & $3,43 \pm 0,671$ & $3,56 \pm 0,489$ \\
FEV1 & $1,53 \pm 0,595$ & $1,84 \pm 0,856$ \\
& & \\
FEV1/FVC & $0,60 \pm 0,205$ & $2,40 \pm 5,094$ \\
& & \\
\hline
\end{tabular}

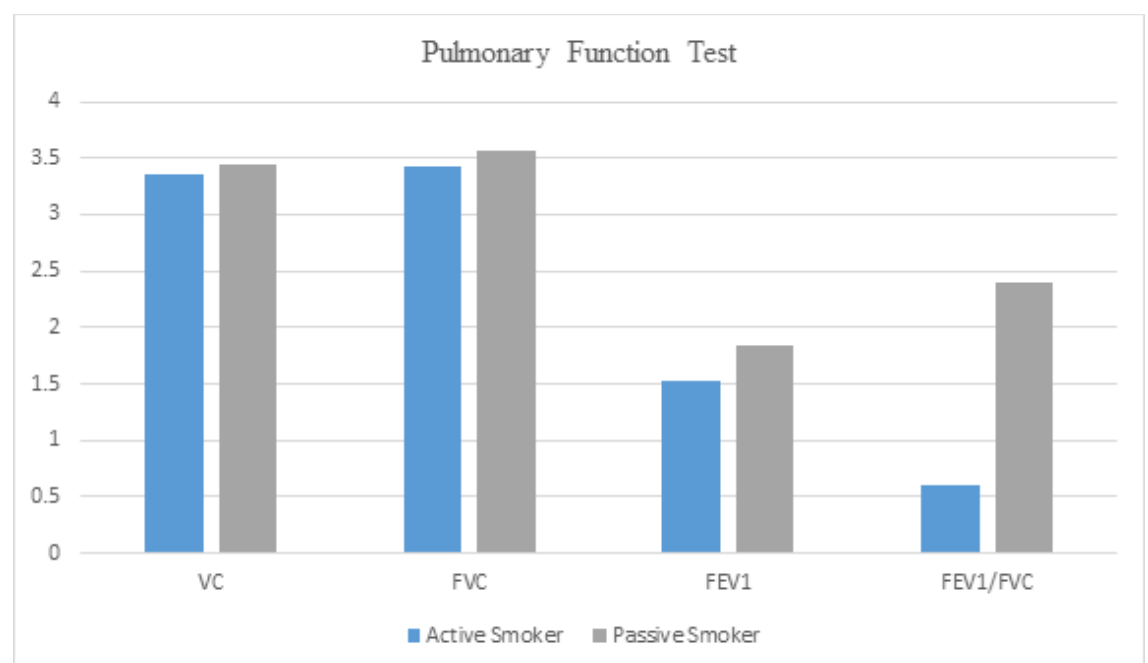

Figure 1. Mean of VC, FVC, FEV1, and FEV1/FVC Ratio of Active and Passive Smoker.

In this study, the total participants with normal results were higher in passive smoker which was 3 participants, and only 1 in active smoker. For moderate COPD, active smoker was higher with 3 participants, while passive smoker with moderate COPD was 2 participants. The amount of severe COPD was high in active smokers with 13 participants, and only 1 in passive smoker. Meanwhile the active smoker with very severe COPD was 4 participants, and in passive smoker was 3 very severe COPD. (Table 3) (Figure 2) 
Table 3. Interpretation of Active and Passive Lung Function Test.

No Classification of COPD

Active smoker

$1 \quad$ Normal

$2 \quad$ Mild

$3 \quad$ Moderate

$4 \quad$ Severe

$5 \quad$ Very Severe
Group

Passive smoker
0

2

$13-1$

4
3

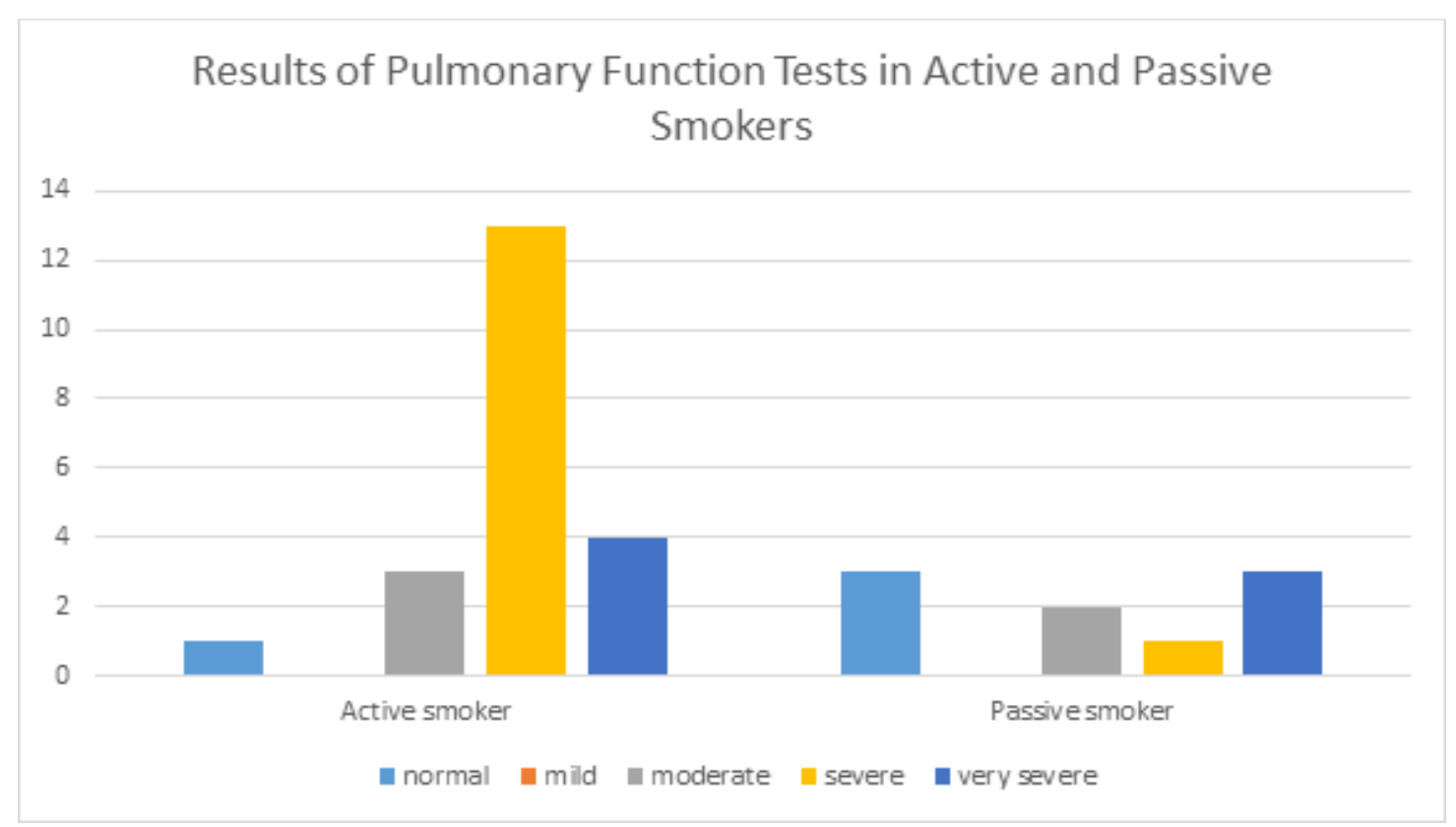

Figure 2. Interpretation of Lung Functional Test of Active and Passive Smoker. 
Current authoritative spirometry guidelines use percentage of FEV1/ FVC ratios (FEV1/FVC\%) to define airway obstruction. The American Thoracic Society/European Respiratory Society Task Force characterizes obstruction as a $\mathrm{FEV} 1 / \mathrm{FVC} \%$ below the statistically defined fifth percentile of normal. However, many recent publications continue to use the Global Initiative for Chronic Obstructive Pulmonary Disease (COPD) primary criterion that defines obstruction as a FEV1/FVC \% <70\% (James E.H.,2007).

Interpretation of spirometry showing obstruction means that it occurs narrowing of the airways and disorders the air flow in it affects the work of deep breathing overcome non-elastic resistance and will manifests in decreased volume Dynamic. This disorder is in the form of a decrease FEV1/FVC ratio $<70 \%$. FEV1 will always be reduced in the incidence of airway obstruction and can occur in large quantities while FVC cannot reduced. In healthy people, it can be decrease in FEV1/FVC ratio but FEV1 and FVC remain normal. Active tobacco smoker (indication of decrease in FEV1/FVC) $7.2 \% ; \mathrm{p}<0.001$ ) and in passive smokers (decreased FEV1/FVC decrease of 3.4\%; $\mathrm{p}=0.005$ ), tobacco cigarettes impair lung function. Effects of smoking on lung function tests show that smoking will cause constriction of medium and large size airways as a result of the length of smoking history (Boskabady et al., 2011). Not just smoking, but cigarette smoke can cause local damage to the ducts breathing, such as loss of cilia function. Cilia serve as a dispelling foreign object that enter the nasal cavity, so that foreign objects and other pollutants won't be easy to get into the lungs. This decrease in cilia function increases risk of lung disorders, because dust and pollutants can be easy to get into the lungs. Cigarette smoke can decrease pulmonary function, lung function disorders is not only experienced in active smokers and former smokers, but can be also experienced by passive smoking (Ardam and Yolanda, 2015).

Cigarette smoke is a mixture of particles and gases. On each Cigarette smoke there are free radicals, namely hydroxide radicals (OH-). Most of these free radicals will arrive at the alveolus while smoking cigarettes. These particles are oxidants that can damage the lungs. The pulmonary parenchymal damage by oxidants occurs due to damage the walls of the alveolus and the onset of modification of anti-elastase function in the airway. Anti-elastase works inhibiting neutrophile. oxidants cause this function disrupted, so that it makes damage of alveolus interstitial. Particulate smoke and polluted air settles on the mucous layer that coats the bronchial mucosa that can inhibits cilia activity. The movement of fluids lining the mucosa is reduced that make irritation of mucosal cells increases (Kathryn, 2010).

Chronic obstructive pulmonary disease (COPD) is one of the diseases or lung disorders that provide ventilation abnormalities in the form of airways obstruction disorders. Obstruction disorder that occurs has a bad impact because it causes impaired oxygenation with all Impact. Airway obstruction that occurs can be worse if any other disorders such as respiratory infections and acute exacerbations of the disease. Airway obstruction in COPD is irreversible and occurs because structural changes in the small airways: inflammation, fibrosis, goblet cells metaplasia and smooth muscle hypertrophy are the main causes of airway obstruction (Kathryn, 2010)

A proper concern is whether the FVC alone, without obtaining the slow or unforced VC for expressing the percentage of FEV1/VC, suffices as a denominator in as certaining the presence of airway obstruction. In our experience, when evaluating a general population, the VC and FVC are usually quite similar; but with moderateto-severe obstructive disease, the VC may be considerably larger, strengthening the evidence of airway obstruction (Brusasco V,1997).

Factors that affect the lung vital capacity depend on the type of exercise. Resistance sports such as weight training rely heavily on anaerobic metabolism. While in aerobic exercise is strongly influenced by muscle ability, cardiovascular and respiration. The effect of muscle capacity on submaximal exercise is explained by an increase in the number of muscle mitochondria and capillaries during endurance training. Research shows $65 \%$ of the maximum value of ventilation work occurs when cardiac output reaches $90 \%$ of the maximum value. When exercise begins, the mechanoreceptors and proprioceptors in the muscles and joints transmit information about movement to the descendent pathway of the motoric cortex and toward the respiratory control center in the medulla oblongata so that ventilation will improve. With continued muscle contraction sensory information gives feedback to the respiratory control center to ensure balanced of 
ventilation and oxygen use. Hyperventilation due to exercise maintains normal arterial PO2 and PCO2 by stabilizing alveolar ventilation appropriate to the level of exercise performed (Silverthorn, 2012).

Aerobic exercise using a stationary bike for three weeks with frequency of exercise three times a week and exercise intensity for 30 minutes. Significant value for FVC is $\mathrm{P}=0.084$, means there is no significant difference between FVC values before and after exercise $(\mathrm{P}>0.05)$ (Ester Hedison, 2013)

Most of the studies used this systematic review shows there is a significant difference between functions. aerobic sports athletes' lungs compared with nonathletes or nonaerobic athletes. This study measured lung function in particular. Of the two components, vital capacity. Lung (VC/FVC) and Forced Expiratory Volume in 1 minute (FEV1). Where Vital capacity of the lungs can be used. to see endurance the lungs of someone. Vital capacity value Higher can be connected. with higher endurance (Fickenword,2020). Increased lung capacity can also be It shows an increase in strength and elasticity of respiratory muscles (Cicek G,2018). FEV1 is commonly used for showing smooth airflow who visited the respiratorium tract (Rawashdeh A,2018). FVC and FEV1 values can be affected by some things outside of routine physical exercise such as gender, height and Body Mass Index (BMI). Known From previous studies that Male lung vital capacity is higher Compared to women, where this is connected with height and surface area of the body Men who are known to be taller than woman. It can be concluded that the larger the surface area of the body Someone will get bigger in volume and Lung size, as well as more oxygen inhaled and exhaled (Fickenword, 2020). Therefore, gender, height and BMI includes confounding factors or factor, and do matching characteristics of height, weight body and BMI.

Some studies that don't see the effects of aerobic exercise to improved lung function viewed through the value of the vital capacity of the lungs and FEV1. Study from Malik et al. (2017) explain the cause of the results insignificant can occur if there is possible bias of the control group where they significantly have higher BMI than with a group of aerobic athletes or anaerobic (Malik, 2017). Rakovac et al. (2018) in Serbia, there is no difference in FVC values and FEV1 in the aerobics, anaerobic athlete group and non-athlete ccaused of a significant difference between anthropometric measurements in any group that make the appearance of bias (Rakovac, 2018).

Effect of aerobic exercise on lung function clarified by the results of experimental studies which provides aerobics intervention, where moderate intensity of aerobic exercise routine for 12 weeks can increase FVC and FEV1 significantly, while the sport high intensity aerobics for 3 weeks can only increase FEV1 Significantly (Anak Agung, 2021).

\section{Conclusion}

Effect of aerobic exercise on lung function clarified by the results of experimental studies which provides aerobics intervention, where moderate intensity of aerobic exercise routine for 12 weeks can increase FVC and FEV1 significantly, while the sport high intensity aerobics for 3 weeks can only increase FEV1 Significantly. Some studies that don't see the effects of aerobic exercise to improved lung function viewed through the value of the vital capacity of the lungs and FEV1, there is no difference in FVC values and FEV1 in the aerobics, anaerobic athlete group and non-athlete caused of a significant difference between anthropometric measurements in any group that make the appearance of bias.

In this study, the total participants with normal results were higher in passive smoker which was 3 $(33,333 \%)$ participants, and only $1(4,761 \%)$ in active smoker. For moderate COPD, passive smoker was higher with $2(22,222 \%)$ participants, while active smoker with moderate COPD was $3(14,286 \%)$ participants. The amount of severe COPD was high in active smokers with $13(61,905 \%)$ participants, and only $1(11,111 \%)$ in passive smoker. Meanwhile the active smoker with very severe COPD was $4(19,047 \%)$ participants, and in passive smoker was $3(33,333 \%)$ very severe COPD.

Active and passive smokers have an equally greater risk of lung tissue damage. In cigarette smoke there are free radicals, namely hydroxide radicals (OH-). Most of these free radicals that will arrive at the 
alveolus while smoking cigarettes or inhale cigarette smoke in passive smoker. These particles are oxidants that can damage the lungs, the pulmonary parenchymal damage by oxidants occurs due to damage the walls of the alveolus and the onset of modification of anti-elastase function in the airway.

\section{Acknowledgments}

We thank Indonesian Government through the Directorate General of Higher Education, which has provided financial assistance for this research through the PKKM grant program. Additionally, we thank EJA Team, Indonesia for editing the manuscript.

\section{References}

Anak Agung Ratih Kusumadewi Wiraputri, I Nyoman Gede Wardana, Yuliana, Muliani. Perbandingan Kapasitas vital paru dan FEV1 antara atlet olahraga aerobic dan nonatlet sebuah tinjauan sistematis; Intisari Sains Medis. 2021; 12(1): 152-157.

Ardam Yolanda KA. Analisis Hubungan Paparan Debu dengan Gangguan Faal Paru Pekerja Overhaul Power Plant (Studi di PT PJB Unit Pelayanan Pemeliharaan Wilayah Timur). Doctoral Dissertation. Universitas Airlangga; 2015.

Bakhtiar A, Tantri RIE. Faal Paru Dinamis. Jurnal Respirasi. 2019; 3(3): 89.

Brusasco V, Pelligrino R, Rodarte JR. Vital capacities in acute and chronic airway obstruction: dependence on flow and volume histories. Eur Respir J. 1997; 10: 1316-1320.

Çiçek G, Güllu A, Güllu E, Yamaner F. The effect of aerobic and core exercises on forced vital capacity. Phys Cult Sport Stud Res. 2018; 77(1):41-7.

Carlos Alberto de Castro Pereira, Andrezza Araujo Oliveira Duarte, Andrea Gimenez, Maria Raquel Soares; Comparison between reference values for FVC, FEV1, and FEV1 /FVC ratio in White adults in Brazil and those suggested by the Global Lung Function Initiative 2012; J Bras Pneumol. 2014; 40(4): 397-402.

Ester Florencia Sagay, Hedison Polii, Herlina IS Wungouw. Pengaruh Latihan Aerobik Terhadap Forced Vital Capacity (FVC) Pria Dewasa dengan Overweight Sagay. e-Biomedik. 2013; 1(1).

Fickenworth L. Effects of Different Aerobic Training Techniques on Vital Capacity and Breath Hold. Aurora: The Research Journal of Ohio Northern University. 2020; 1(1).

James EH, Xing-Guo S, Karlman W. Spirometric Criteria for Airway Obstruction* Use Percentage of FEV1/FVC Ratio Below the Fifth Percentile, Not $<70 \%$. Chest. 2007; 131(20).

Kathryn L Mc Cance. Pathophysiology. The Biologic Basis for Disease in Adults and Children, 6 th ed. Canada. Mosby. Pg. 1286-1290; 2010.

Kusuma ARP. Pengaruh merokok terhadap kesehatan gigi dan rongga mulut. Majalah Ilmiah Sultan Agung. 2020; 49(124): 12-19.

Lontoh SO. Pengaruh rokok terhadap fungsi paru mahasiswa Teknik Sipil Universitas Tarumanagara Jakarta Barat 2016. Journal of Physical Therapy Science. 2019; 2(1): 119-123.

Malik DA, Malik DS, Kumar S. Sports Specific Influence on Force Vital Capacity in University Players. IOSR J Sport Phys Educ. 2017; 04(02): 6-9.

Rachmat M. Pengembangan Ekonomi Tembakau Nasional: Kebijakan Negara Maju dan Pembelajaran Bagi Indonesia. Analisis Kebijakan Pertanian. 2016; 8(1), 67.

Rakovac A, Andric L, Karan V, Bogdan M, Slavic D, Klasnja A. Evaluation of spirometric parameters and maximum oxygen consumption in athletes and non-athletes. Med Pregl Rev. 2018; 71(5-6): 157-61.

Rawashdeh A, Alnawaiseh N. The effect of high intensity aerobic exercise on the pulmonary function among inactive male individuals. Biomed Pharmacol J. 2018; 11(2): 735-41.

Silverthorn DU. Fisiologi Manusia sebuah pendekatan terintegrasi. In S. Y. Antonia Tanzil, Sri redjeki (Ed.), EGC (6th ed., pp. 870-879); 2012.

WHO. (2020). Pernyataan: Hari Tanpa Tembakau Sedunia 2020 (pp. 10-12). 
https://www.who.int/indonesia/news/detail/30-05-2020-pernyataan-hari-tanpa-tembakau-sedunia-2020 